Opinion

\title{
The Second Wave of COVID-19 Pandemic Strikes during the Flu Season: An Awareness Perspective
}

\author{
Alexandru Burlacu ${ }^{1,2,+}+(\mathbb{D}$, Radu Crisan-Dabija $2,3,+(\mathbb{D}$, Iolanda Valentina Popa $2, *(\mathbb{D})$ \\ and Adrian Covic ${ }^{2,4}$ \\ 1 Department of Interventional Cardiology—Cardiovascular Diseases Institute, 700503 Iasi, Romania; \\ alburlacu@yahoo.com \\ 2 Department of Internal Medicine, 'Grigore T. Popa' University of Medicine and Pharmacy, \\ 700115 Iasi, Romania; crisanradu@gmail.com (R.C.-D.); accovic@gmail.com (A.C.) \\ 3 Pulmonology Department, Clinic of Pulmonary Diseases, 700115 Iasi, Romania \\ 4 Nephrology Clinic, Dialysis, and Renal Transplant Center- 'C.I. Parhon' University Hospital, \\ 700503 Iasi, Romania \\ * Correspondence: iolivp@gmail.com; Tel.: +40-72-365-1930 \\ + Both authors contributed equally.
}

Received: 14 November 2020; Accepted: 16 December 2020; Published: 18 December 2020

\begin{abstract}
Coinfection with both SARS-CoV-2 and influenza viruses seems to be a real and severe problem. However, coinfection is far from a simple matter, and cannot be considered having more unfavorable outcomes as a direct consequence. In reality, the aftermath is powerfully nuanced by the presence of risk factors and specific molecular mechanisms. Our objective was to raise awareness around the unpredictable association between COVID-19 pandemics and the upcoming flu season, and make arguments about the need to develop new routine testing protocols for both viruses, at least during the period with an expected high incidence. Our reasoning is built around the various impacts that the whole range of risk groups, common immunological mechanisms, and complex interactions, such as influenza vaccination, will have on patients' prognosis. We show that the more flawed clinical course is due to managing only one of the infections (and, subsequently, neglecting the other condition).
\end{abstract}

Keywords: COVID-19; SARS-CoV-2; flu season; influenza virus; coinfections

\section{Introduction}

"Winter is coming" and with it comes the flu season. In most countries, the second wave of COVID-19 is manifesting. Not only do both viruses arrive at once, but they can come together. Coinfection with both respiratory viruses seems to be a real and severe problem. Drawing two non-winning lotteries seems hard to believe, but several complex evolution cases are already described [1].

The issue of coinfection is far from a simple matter and cannot be considered to have more unfavorable outcomes. In reality, the aftermath is powerfully nuanced by a whole range of risk groups, common immunological mechanisms, and complex interactions, such as influenza vaccination, with an undeniable impact on patients' prognosis.

Viral coinfection seems not to have a linear worsening; therefore, several questions remain to be answered: Which of the viruses poses a greater risk of death? Wherewith the flu vaccine influences COVID-19 infection? What common mechanisms can be targeted by (old and novel) therapies, as failing to diagnose one of the infections may also lead to inappropriate treatment? 


\section{Is There a Specific Category of Patients Prone to Viral Coinfection?}

The answer to this question is far from clear. However, there are some categories with specific risk for unfavorable disease course. The importance of correctly identifying risk groups derives from the need to initiate appropriate treatment in a timely manner, as early treatment may lessen the risk of hospitalization and death [2].

Firstly, a retrospective study of the 2009 H1N1pdm influenza pandemic showed that a pre-existing chronic condition (older age [3], obesity, Type 2 diabetes mellitus, respiratory or cardiovascular diseases [4]) increased the likelihood of ICU admittance and fatal outcomes [5]. Hypertension, other cardiovascular diseases, and older age seem to be critical risk factors for both flu and COVID-19 severity, as was shown in a recent meta-analysis [6]. Obesity appears to be one of the most critical risk factors for both critical forms of H1N1 infection and severe COVID-19 [7]. A disruptive effect of the adipocytes [8] is at the front of disturbances in inflammatory crosstalk between leukocyte-mediated processes and molecular signaling [9], and alterations in leukocyte population and lymphocyte activity, leading to an insufficient immunological response $[9,10]$ and predisposing to respiratory infections (particularly to severe forms of both COVID-19 [11] and influenza [12]).

Secondly, physical inactivity and insulin resistance interfere with macrophage activation and inhibit pro-inflammatory cytokines, predisposing obese patients to a double risk of contracting both viruses [13]. Type 2 diabetes quadruples the risk of hospitalization with severe forms of H1N1p infection [14,15]. Since the angiotensin-converting enzyme 2 (ACE2) receptor expression is significantly higher in Type 1 and Type 2 diabetes [16], these patients are at a double infection risk for SARS-CoV-2, according to several studies [6,17].

Thirdly, chronically ill respiratory patients (particularly chronic obstructive pulmonary disease [18] or tuberculosis sequelae) risk contracting both influenza and SARS-CoV-2 [19]. Active or past tuberculosis has an increased risk of severe outcomes during influenza infection $[20,21]$ and a significantly higher risk for severe SARS-Cov-2 infection [22].

Fourthly, pregnant women were identified as being at increased risk for hospitalization and severe disease during the $2009 \mathrm{H} 1 \mathrm{~N} 1 \mathrm{pdm}$ influenza pandemic [5], while pregnant and recently pregnant women with COVID-19 were shown to be at increased risk of admission to an intensive care unit, according to the results of a recent meta-analysis [23].

Fifthly, oncologic patients under active treatment infected with SARS-CoV-2 were found to have worse outcomes in terms of mortality and respiratory failure rates, compared with COVID-19 in the general population [24]. Similarly, patients diagnosed with cancer or individuals under immunosuppressant medication were significantly associated with fatal outcomes when infected with influenza [25,26]. However, for immunocompromised individuals with COVID-19, "current studies have not shown worse outcomes, except for patients with cancer" [27].

Any of these patients should be carefully considered at risk for coinfection when respiratory symptoms are present.

\section{Is One Plus One Equal to Two? The Clinical Outcomes of Patients Infected with Both SARS-CoV-2 and Influenza Viruses}

Once one [1] has noted the increasing incidence of the two viruses' coexistence, a legitimate question arises: does the presence of the two in the same patient determine a more severe evolution than each taken separately? A fair answer is relevant, as both viruses mimic each other, regarding clinical presentation, transmission, and seasonal coincidence. This important overlap may mask possible coinfections and may lead to inappropriate treatment strategies when clinical outcomes of viral coexistence are not known.

In other words: does one plus one equal two, or 0.5 , or 4 ? To date, there is no observational study to assess coinfected patients' evolution and outcomes compared to those infected with SARS-CoV-2 or other distinct respiratory viruses. What is clear is that an erroneous diagnostic, treatment, or both 
(either for COVID-19 or for the flu) can allow the clinical course of the other coinfectant to be "natural" (more severe) [28].

Several small case series have been published to date. Two small case series studies published in China reported, on the one hand, that "coinfection patients did not appear to experience a more difficult situation," and, on the other hand, that "we cannot ignore COVID-19 infection patients might combine with other respiratory viruses" [29-31]. Another two case series in which almost all patients had a medical history of hypertension, and a significant proportion of them were diabetic or on hemodialysis, were published. Although almost all patients were classified as being part of high-risk categories, their clinical evolution did not differ from previously reported monoinfections with SARS-CoV-2 [32,33]. However, severe or fatal COVID-19 outcomes have also been described in isolated case reports of coinfections with influenza [34] or other viral, bacterial [35], or fungal pathogens (especially Aspergillus fumigatus) [36].

Another theory is that one of the respiratory viruses can actively help a viral strain (e.g., SARS-CoV-2) to invade, and thus, patients who otherwise would not have had COVID-19 would become infected with a significant viral load [37]. On the other hand, a study reporting on coinfection rates between SARS-CoV-2 and other respiratory viral and bacterial pathogens showed "no significant difference in rates of SARS-CoV-2 infection in patients with and without other pathogens" [38].

Moreover, a mathematical model of coinfections indicates that viruses with a faster growth rate will suppress viruses with a slower growth rate, in a viral competition for resources [39]. SARS-CoV-2 has a slower growth rate than influenza, indicating that SARS-CoV-2 replication may be suppressed when the novel coronavirus infection is initiated simultaneously or after the influenza infection [40]. When SARS-CoV-2 is the first to meet the human body, the suppression may be mitigated, to a limited extent [40]. If the suppression theory proves to be right, the therapeutic conduct should be adapted accordingly, since treating the influenza infection might warrant greater susceptibility for SARS-CoV-2. This emphasizes, even more, the importance of testing all symptomatic patients for both viruses, to make informed therapeutic decisions.

\section{The Immunological Mechanisms of Influenza Infection Predisposing to SARS-CoV-2 Coinfection and Severity}

In order to deepen the knowledge on viral coexistence beyond clinical symptoms, the study of molecular mechanisms may be able to explain already-known manifestations and may anticipate unrevealed clinical outcomes. A significant determinant of coinfection dynamics is the immune response by regulating viral entry sites and upregulating or downregulating different inflammatory pathways and receptors involved in the overall response to infection.

A critical immune response of the COVID-19-flu interaction might be the toll-like receptor 4 (TLR4). COVID-19 patients upregulate TLR4 pro-inflammatory signaling, as TLR4 is most likely responsible for recognizing molecular patterns from SARS-CoV-2 [41]. The TLR4 signaling response in COVID-19 may cause influenza to induce acute lung injury/acute respiratory distress syndrome [42] or a TLR4-dependent "cytokine storm" similar to septic shock [43].

Severe SARS-CoV-2 and influenza infections overproduce a large number of proinflammatory cytokines, generating a cascade of events ("cytokine storm") that is difficult to manage. Severe COVID-19 and influenza infections caused by highly virulent subtypes, such as H1N1 and $\mathrm{H} 5 \mathrm{~N} 1$, are both characterized by overinduction of the proinflammatory cytokines tumor necrosis factor- $\alpha$ and monocyte chemoattractant protein-1 [44]. In this context, a possible coinfection may induce a positive feedback loop of cytokine production, speeding up the process of respiratory deterioration.

Moreover, both influenza and SARS-CoV-2 have been demonstrated to enhance monocyte tissue factor (TF) expression. TF activates platelets via TLRs that interact with neutrophils to facilitate neutrophil extracellular traps, supporting the process of immunothrombosis [45], ultimately causing (micro)thrombotic complications, such as deep vein thrombosis, pulmonary embolism, and stroke. It is noteworthy that both capillary microthrombi and pulmonary macrothrombi were shown to 
be significantly more prevalent in patients with COVID-19 than in patients with influenza A [46]. Although no papers studying the dynamic of thrombosis in case of coinfection are yet published, coinfections of influenza with other respiratory pathogens were shown to increase mortality and lead to more severe disease characterized by capillary thrombosis, zones of vasculitis, and necrosis surrounding areas of bronchiolar damage [47].

Additionally, furin is a type 1 membrane-bound protease expressed in multiple tissues that can cleave both SARS-CoV-2 [48] and influenza [49] surface glycoproteins that, in turn, increase viral ability to permeate the host cell membrane. The massive increase of active TGF- $\beta$ in COVID-19 likely surges furin expression [50], facilitating the binding of ACE2 to the viral S protein through cleavage. Influenza has similar cleavage sites acted upon by furin [49], resulting in higher virulence for both influenza and SARS-CoV-2.

Interestingly, the molecular interplay between SARS-CoV-2 and human lung tissue (from the initial phase of receptor binding to viral replication) was explored in the context of a network analysis in systems biology by constructing lung protein interactomes. Thereby, 50 hub proteins of the replication machinery network were noticed both in influenza and SARS-CoV-2 infection, suggesting similar mechanisms of viral replication and viral-host interactions [51]. This may have important therapeutic implications regarding appropriate treatment strategies in case of coinfection.

A possible protective effect of influenza against SARS-CoV-2 infection was also discussed. The downregulation of ACE2 by the influenza virus [52] may lower susceptibility to infection.

\section{Effects of Influenza Vaccination on the Risk of SARS-CoV-2 Infection}

Since the introduction of influenza vaccination, a significant number of lives have been spared [53]. Each winter, the impact of influenza infection on older people can lead to up to 60,000 deaths in Europe alone [54]. Preceding the influenza pandemic, vaccination of diabetes patients has been shown to reduce hospitalization [55] significantly. Vaccination reduces the risk of ICU admittance of older adults with diabetes (due to respiratory failure and viral pneumonia), significantly lowering the risk of death [56].

Most international management guidelines for patients with chronic respiratory diseases recommend influenza vaccination [57], giving concrete evidence to reduce severe exacerbations and death risk [58]. However, recent data on the effectiveness of the influenza vaccines looking into long-term cell-mediated immunity [59] seems to be a future-proof direction in providing broad protection and optimized vaccination, especially in the abovementioned high-risk groups [60].

The idea of providing cell-mediated immunity is not new, and is based on restoring the Th1 cell immunity while downregulating the cytokine storm with IL-6 [61].

The question (with no valid answer, whatsoever) of using the cell-mediated immunity in a SARS-CoV-2 vaccine has been recently raised [62]. Nevertheless, current data instead sustain the idea that an influenza vaccine can provide cross-immunity protection against coronaviruses infection [63]. It is at least possible that, through the bystander effect [64], the population already vaccinated with influenza vaccine can show less susceptibility or milder symptoms of COVID-19 [65] on top of an obvious protection against the aggressive influenza virus.

\section{Conclusions}

The first conclusion to be retained by practitioners is that a high degree of suspicion regarding coinfection should be maintained. Routine testing protocols will need to be developed for both viruses during the period with an expected high incidence. Data on the severity and clinical course of coinfection are contradictory. Some evidence indicates no worse clinical outcome during coinfection, while others indicate a higher [66], or even lower [67], mortality during the coexistence of COVID-19 and seasonal flu. Due to cross-reactivity between flu and COVID-19, it is advocated that influenza vaccination might have more beneficial effects on COVID-19 than measles, mumps, rubella (MMR) and 
bacillus Calmette-Guérin (BCG) vaccines [65]. What is clear, for now, is that the more flawed clinical course is due to managing only one of the infections (and subsequently neglecting the other condition).

Author Contributions: Conceptualization: A.B. and R.C.-D.; methodology: A.B. and R.C.-D.; investigation: A.B. and R.C.-D.; resources: A.B., R.C.-D., and I.V.P.; writing-original draft preparation: A.B., R.C.-D., and I.V.P.; writing-review and editing: A.B., R.C.-D., and A.C.; supervision: A.B., R.C.-D., and A.C. All authors have read and agreed to the published version of the manuscript.

Funding: This research received no specific grant from any funding agency in the public, commercial, or not-for-profit sectors.

Conflicts of Interest: The authors declare that there are no conflicts of interest.

\section{References}

1. Center, S.M.N. COVID-19 Patients Often Infected with Other Respiratory Viruses, Preliminary Study Reports. Available online: https://med.stanford.edu/news/all-news/2020/03/covid-19-can-coexist-with-otherrespiratory-viruses.html (accessed on 17 October 2020).

2. McCullough, P.A.; Kelly, R.J.; Ruocco, G.; Lerma, E.; Tumlin, J.; Wheelan, K.R.; Katz, N.; Lepor, N.E.; Vijay, K.; Carter, H.; et al. Pathophysiological Basis and Rationale for Early Outpatient Treatment of SARS-CoV-2 (COVID-19) Infection. Am. J. Med. 2020. [CrossRef] [PubMed]

3. Zhou, F.; Yu, T.; Du, R.; Fan, G.; Liu, Y.; Liu, Z.; Xiang, J.; Wang, Y.; Song, B.; Gu, X.; et al. Clinical course and risk factors for mortality of adult inpatients with COVID-19 in Wuhan, China: A retrospective cohort study. Lancet 2020, 395, 1054-1062. [CrossRef]

4. ECDC. High-Risk Groups for COVID-19. Available online: https://www.ecdc.europa.eu/en/covid-19/highrisk-groups (accessed on 17 October 2020).

5. Van Kerkhove, M.D.; Vandemaele, K.A.; Shinde, V.; Jaramillo-Gutierrez, G.; Koukounari, A.; Donnelly, C.A.; Carlino, L.O.; Owen, R.; Paterson, B.; Pelletier, L.; et al. Risk factors for severe outcomes following 2009 influenza A (H1N1) infection: A global pooled analysis. PLoS Med. 2011, 8, e1001053. [CrossRef] [PubMed]

6. de Almeida-Pititto, B.; Dualib, P.M.; Zajdenverg, L.; Dantas, J.R.; de Souza, F.D.; Rodacki, M.; Bertoluci, M.C. Severity and mortality of COVID 19 in patients with diabetes, hypertension and cardiovascular disease: A meta-analysis. Diabetol. Metab. Syndr. 2020, 12, 75. [CrossRef] [PubMed]

7. Louie, J.K.; Acosta, M.; Winter, K.; Jean, C.; Gavali, S.; Schechter, R.; Vugia, D.; Harriman, K.; Matyas, B.; Glaser, C.A.; et al. Factors associated with death or hospitalization due to pandemic 2009 influenza A(H1N1) infection in California. JAMA 2009, 302, 1896-1902. [CrossRef] [PubMed]

8. Andersen, C.J.; Murphy, K.E.; Fernandez, M.L. Impact of Obesity and Metabolic Syndrome on Immunity. Adv. Nutr. 2016, 7, 66-75. [CrossRef] [PubMed]

9. Kanneganti, T.-D.; Dixit, V.D. Immunological complications of obesity. Nat. Immunol. 2012, 13, 707-712. [CrossRef]

10. Nave, H.; Beutel, G.; Kielstein, J.T. Obesity-related immunodeficiency in patients with pandemic influenza H1N1. Lancet. Infect. Dis. 2011, 11, 14-15. [CrossRef]

11. Ong, S.W.X.; Young, B.E.; Leo, Y.S.; Lye, D.C. Association of higher body mass index (BMI) with severe coronavirus disease 2019 (COVID-19) in younger patients. Clin. Infect. Dis. Off. Publ. Infect. Dis. Soc. Am. 2020. [CrossRef]

12. Karlsson, E.A.; Sheridan, P.A.; Beck, M.A. Diet-induced obesity in mice reduces the maintenance of influenza-specific CD8+ memory T cells. J. Nutr. 2010, 140, 1691-1697. [CrossRef]

13. Luzi, L.; Radaelli, M.G. Influenza and obesity: Its odd relationship and the lessons for COVID-19 pandemic. Acta Diabetol. 2020, 57, 759-764. [CrossRef] [PubMed]

14. Allard, R.; Leclerc, P.; Tremblay, C.; Tannenbaum, T.N. Diabetes and the severity of pandemic influenza A (H1N1) infection. Diabetes Care 2010, 33, 1491-1493. [CrossRef] [PubMed]

15. Jiménez-García, R.; Hernández-Barrera, V.; Rodríguez-Rieiro, C.; Lopez de Andres, A.; de Miguel-Diez, J.; Jimenez-Trujillo, I.; Gil de Miguel, A.; Carrasco-Garrido, P. Hospitalizations from pandemic Influenza [A(H1N1)pdm09] infections among type 1 and 2 diabetes patients in Spain. Influenza Other Respir. Viruses 2013, 7, 439-447. [CrossRef] [PubMed] 
16. Wan, Y.; Shang, J.; Graham, R.; Baric, R.S.; Li, F. Receptor Recognition by the Novel Coronavirus from Wuhan: An Analysis Based on Decade-Long Structural Studies of SARS Coronavirus. J. Virol. 2020, 94. [CrossRef] [PubMed]

17. Guo, W.; Li, M.; Dong, Y.; Zhou, H.; Zhang, Z.; Tian, C.; Qin, R.; Wang, H.; Shen, Y.; Du, K.; et al. Diabetes is a risk factor for the progression and prognosis of COVID-19. Diabetes/Metab. Res. Rev. 2020. [CrossRef] [PubMed]

18. CDC. People with Certain Medical Conditions. Available online: https://www.cdc.gov/coronavirus/2019ncov/need-extra-precautions/people-with-medical-conditions.html (accessed on 17 October 2020).

19. Jordan, R.E.; Adab, P.; Cheng, K.K. Covid-19: Risk factors for severe disease and death. BMJ 2020, 368 , m1198. [CrossRef]

20. Walaza, S.; Cohen, C.; Nanoo, A.; Cohen, A.L.; McAnerney, J.; von Mollendorf, C.; Moyes, J.; Tempia, S. Excess Mortality Associated with Influenza among Tuberculosis Deaths in South Africa, 1999-2009. PLoS ONE 2015, 10, e0129173. [CrossRef]

21. Oei, W.; Nishiura, H. The relationship between tuberculosis and influenza death during the influenza (H1N1) pandemic from 1918-19. Comput. Math. Methods Med. 2012, 2012, 124861. [CrossRef]

22. Crisan-Dabija, R.; Grigorescu, C.; Pavel, C.A.; Artene, B.; Popa, I.V.; Cernomaz, A.; Burlacu, A. Tuberculosis and COVID-19: Lessons from the Past Viral Outbreaks and Possible Future Outcomes. Can. Respir. J. 2020, 2020, 1401053. [CrossRef]

23. Allotey, J.; Stallings, E.; Bonet, M.; Yap, M.; Chatterjee, S.; Kew, T.; Debenham, L.; Llavall, A.C.; Dixit, A.; Zhou, D.; et al. Clinical manifestations, risk factors, and maternal and perinatal outcomes of coronavirus disease 2019 in pregnancy: Living systematic review and meta-analysis. BMJ 2020, 370, m3320. [CrossRef]

24. Yarza, R.; Bover, M.; Paredes, D.; López-López, F.; Jara-Casas, D.; Castelo-Loureiro, A.; Baena, J.; Mazarico, J.M.; Folgueira, M.D.; Meléndez-Carmona, M.; et al. SARS-CoV-2 infection in cancer patients undergoing active treatment: Analysis of clinical features and predictive factors for severe respiratory failure and death. Eur. J. Cancer 2020, 135, 242-250. [CrossRef] [PubMed]

25. Adlhoch, C.; Gomes Dias, J.; Bonmarin, I.; Hubert, B.; Larrauri, A.; Oliva Domínguez, J.A.; Delgado-Sanz, C.; Brytting, M.; Carnahan, A.; Popovici, O.; et al. Determinants of Fatal Outcome in Patients Admitted to Intensive Care Units With Influenza, European Union 2009-2017. Open Forum Infect. Dis. 2019, 6, ofz462. [CrossRef] [PubMed]

26. Kunisaki, K.M.; Janoff, E.N. Influenza in immunosuppressed populations: A review of infection frequency, morbidity, mortality, and vaccine responses. Lancet. Infect. Dis. 2009, 9, 493-504. [CrossRef]

27. Cajamarca-Baron, J.; Guavita-Navarro, D.; Buitrago-Bohorquez, J.; Gallego-Cardona, L.; Navas, A.; Cubides, H.; Arredondo, A.M.; Escobar, A.; Rojas-Villarraga, A. SARS-CoV-2 (COVID-19) in patients with some degree of immunosuppression. Reumatol. Clin. 2020. [CrossRef]

28. Corona24News. The Complex Coexistence of COVID-19 and Influenza. Available online: https://www. corona24news.com/c/2020/09/08/the-complex-coexistence-of-covid-19-and-influenza.html (accessed on 17 October 2020).

29. Ding, Q.; Lu, P.; Fan, Y.; Xia, Y.; Liu, M. The clinical characteristics of pneumonia patients coinfected with 2019 novel coronavirus and influenza virus in Wuhan, China. J. Med. Virol. 2020, 92, 1549-1555. [CrossRef] [PubMed]

30. Shah, N. Higher Co-Infection Rates in COVID19. Available online: https://medium.com/@nigam/higher-coinfection-rates-in-covid19-b24965088333 (accessed on 17 October 2020).

31. Zheng, X.; Wang, H.; Su, Z.; Li, W.; Yang, D.; Deng, F.; Chen, J. Co-infection of SARS-CoV-2 and Influenza virus in Early Stage of the COVID-19 Epidemic in Wuhan, China. J. Infect. 2020, 81, e128-e129. [CrossRef]

32. Cuadrado-Payán, E.; Montagud-Marrahi, E.; Torres-Elorza, M.; Bodro, M.; Blasco, M.; Poch, E.; Soriano, A.; Piñeiro, G.J. SARS-CoV-2 and influenza virus co-infection. Lancet 2020, 395, e84. [CrossRef]

33. Miatech, J.L.; Tarte, N.N.; Katragadda, S.; Polman, J.; Robichaux, S.B. A case series of coinfection with SARS-CoV-2 and influenza virus in Louisiana. Respir. Med. Case Rep. 2020, 31, 101214. [CrossRef]

34. D’Abramo, A.; Lepore, L.; Palazzolo, C.; Barreca, F.; Liuzzi, G.; Lalle, E.; Nicastri, E. Acute respiratory distress syndrome due to SARS-CoV-2 and Influenza A co-infection in an Italian patient: Mini-review of the literature. Int. J. Infect. Dis. Ijid Off. Publ. Int. Soc. Infect. Dis. 2020, 97, 236-239. [CrossRef] 
35. Sohal, S.; Rodriguez-Nava, G.; Khabbaz, R.; Chaudry, S.; Musurakis, C.; Chitrakar, S.; Chundi, V.V.; Friedman, H.J. SARS-CoV2 and Co-Infections: A Review of Two Cases. Case Rep. Infect. Dis. 2020, 2020, 8882348. [CrossRef]

36. Helleberg, M.; Steensen, M.; Arendrup, M.C. Invasive aspergillosis in patients with severe COVID-19 pneumonia. Clin. Microbial. Infect. 2020. [CrossRef] [PubMed]

37. Kissler, S. Will Flu or Cold Viruses Push the New Coronavirus out of Circulation This Winter? Available online: https://theconversation.com/will-flu-or-cold-viruses-push-the-new-coronavirus-out-of-circulationthis-winter-139513 (accessed on 17 October 2020).

38. Kim, D.; Quinn, J.; Pinsky, B.; Shah, N.H.; Brown, I. Rates of Co-infection between SARS-CoV-2 and Other Respiratory Pathogens. JAMA 2020, 323, 2085-2086. [CrossRef] [PubMed]

39. Pinky, L.; Dobrovolny, H.M. Coinfections of the Respiratory Tract: Viral Competition for Resources. PLoS ONE 2016, 11, e0155589. [CrossRef]

40. Pinky, L.; Dobrovolny, H.M. SARS-CoV-2 coinfections: Could influenza and the common cold be beneficial? J. Med Virol. 2020. [CrossRef]

41. Choudhury, A.; Mukherjee, S. In silico studies on the comparative characterization of the interactions of SARS-CoV-2 spike glycoprotein with ACE-2 receptor homologs and human TLRs. J. Med. Virol. 2020. [CrossRef]

42. Imai, Y.; Kuba, K.; Neely, G.G.; Yaghubian-Malhami, R.; Perkmann, T.; van Loo, G.; Ermolaeva, M.; Veldhuizen, R.; Leung, Y.H.; Wang, H.; et al. Identification of oxidative stress and Toll-like receptor 4 signaling as a key pathway of acute lung injury. Cell 2008, 133, 235-249. [CrossRef]

43. Zaffaroni, L.; Peri, F. Recent advances on Toll-like receptor 4 modulation: New therapeutic perspectives. Future Med. Chem. 2018, 10, 461-476. [CrossRef]

44. Oberemok, V.V.; Laikova, K.V.; Yurchenko, K.A.; Marochkin, N.A.; Fomochkina, I.I.; Kubyshkin, A.V. SARS-CoV-2 will constantly sweep its tracks: A vaccine containing CpG motifs in 'lasso' for the multi-faced virus. Inflamm. Res. Off. J. Eur. Histamine Res. Soc. 2020, 69, 801-812. [CrossRef]

45. Mackman, N.; Antoniak, S.; Wolberg, A.S.; Kasthuri, R.; Key, N.S. Coagulation Abnormalities and Thrombosis in Patients Infected With SARS-CoV-2 and Other Pandemic Viruses. Arterioscler. Thromb. Vasc. Biol. 2020, 40, 2033-2044. [CrossRef]

46. Burkhard-Koren, N.M.; Haberecker, M.; Maccio, U.; Ruschitzka, F.; Schuepbach, R.A.; Zinkernagel, A.S.; Hardmeier, T.; Varga, Z.; Moch, H. Higher prevalence of pulmonary macrothrombi in SARS-CoV-2 than in influenza A: Autopsy results from 'Spanish flu' 1918/1919 in Switzerland to Coronavirus disease 2019. Clin. Res. 2020. [CrossRef]

47. Morens, D.M.; Taubenberger, J.K.; Fauci, A.S. Predominant role of bacterial pneumonia as a cause of death in pandemic influenza: Implications for pandemic influenza preparedness. J. Infect. Dis. 2008, 198, 962-970. [CrossRef] [PubMed]

48. Coutard, B.; Valle, C.; de Lamballerie, X.; Canard, B.; Seidah, N.G.; Decroly, E. The spike glycoprotein of the new coronavirus 2019-nCoV contains a furin-like cleavage site absent in CoV of the same clade. Antivir. Res. 2020, 176, 104742. [CrossRef] [PubMed]

49. Kido, H.; Okumura, Y.; Takahashi, E.; Pan, H.Y.; Wang, S.; Yao, D.; Yao, M.; Chida, J.; Yano, M. Role of host cellular proteases in the pathogenesis of influenza and influenza-induced multiple organ failure. Biochim. Biophys. Acta 2012, 1824, 186-194. [CrossRef] [PubMed]

50. Thomas, G. Furin at the cutting edge: From protein traffic to embryogenesis and disease. Nat. Rev. Mol. Cell Biol. 2002, 3, 753-766. [CrossRef]

51. Ahmed, S.S.; Paramasivam, P.; Raj, K.; Kumar, V.; Murugesan, R.; Ramakrishnan, V. Interplay of host regulatory network on SARS-CoV-2 binding and replication machinery. bioRxiv 2020. [CrossRef]

52. Liu, X.; Yang, N.; Tang, J.; Liu, S.; Luo, D.; Duan, Q.; Wang, X. Downregulation of angiotensin-converting enzyme 2 by the neuraminidase protein of influenza A (H1N1) virus. Virus Res. 2014, 185, 64-71. [CrossRef]

53. Foppa, I.M.; Cheng, P.Y.; Reynolds, S.B.; Shay, D.K.; Carias, C.; Bresee, J.S.; Kim, I.K.; Gambhir, M.; Fry, A.M. Deaths averted by influenza vaccination in the U.S. during the seasons 2005/06 through 2013/14. Vaccine 2015, 33, 3003-3009. [CrossRef]

54. WHO. Infographic-Vaccination Saves Lives. Available online: https://www.euro.who.int/en/healthtopics/communicable-diseases/influenza/vaccination/infographic-vaccination-saves-lives (accessed on 17 October 2020). 
55. Colquhoun, A.J.; Nicholson, K.G.; Botha, J.L.; Raymond, N.T. Effectiveness of influenza vaccine in reducing hospital admissions in people with diabetes. Epidemiol. Infect. 1997, 119, 335-341. [CrossRef]

56. Wang, I.K.; Lin, C.L.; Chang, Y.C.; Lin, P.C.; Liang, C.C.; Liu, Y.L.; Chang, C.T.; Yen, T.H.; Huang, C.C.; Sung, F.C. Effectiveness of influenza vaccination in elderly diabetic patients: A retrospective cohort study. Vaccine 2013, 31, 718-724. [CrossRef]

57. GOLD. Pocket Guide to COPD Diagnosis, Management, and Prevention. Available online: https: //goldcopd.org/wp-content/uploads/2018/11/GOLD-2019-POCKET-GUIDE-FINAL_WMS.pdf (accessed on 17 October 2020).

58. Bekkat-Berkani, R.; Wilkinson, T.; Buchy, P.; Dos Santos, G.; Stefanidis, D.; Devaster, J.M.; Meyer, N. Seasonal influenza vaccination in patients with COPD: A systematic literature review. BMC Pulm. Med. 2017, 17, 79. [CrossRef]

59. Gianchecchi, E.; Torelli, A.; Montomoli, E. The use of cell-mediated immunity for the evaluation of influenza vaccines: An upcoming necessity. Hum. Vaccines Immunother. 2019, 15, 1021-1030. [CrossRef] [PubMed]

60. Avetisyan, G.; Ragnavölgyi, E.; Toth, G.T.; Hassan, M.; Ljungman, P. Cell-mediated immune responses to influenza vaccination in healthy volunteers and allogeneic stem cell transplant recipients. Bone Marrow Transplant. 2005, 36, 411-415. [CrossRef] [PubMed]

61. O'Donnell, H.; McSorley, S.J. Salmonella as a model for non-cognate Th1 cell stimulation. Front. Immunol. 2014, 5, 621. [CrossRef] [PubMed]

62. Gupta, A. Is Immuno-modulation the Key to COVID-19 Pandemic? Indian J. Orthop. 2020, 54, $394-397$. [CrossRef]

63. Zheng, J.; Perlman, S. Immune responses in influenza a virus and human coronavirus infections: An ongoing battle between the virus and host. Curr. Opin. Virol. 2018, 28, 43-52. [CrossRef]

64. Horns, F.; Dekker, C.L.; Quake, S.R. Memory B Cell Activation, Broad Anti-influenza Antibodies, and Bystander Activation Revealed by Single-Cell Transcriptomics. Cell Rep. 2020, 30, 905-913.e906. [CrossRef]

65. Salem, M.L.; El-Hennawy, D. The possible beneficial adjuvant effect of influenza vaccine to minimize the severity of COVID-19. Med. Hypotheses 2020, 140, 109752. [CrossRef]

66. Zhang, G.; Hu, C.; Luo, L.; Fang, F.; Chen, Y.; Li, J.; Peng, Z.; Pan, H. Clinical features and short-term outcomes of 221 patients with COVID-19 in Wuhan, China. J. Clin. Virol. Off. Publ. Pan Am. Soc. Clin. Virol. 2020, 127, 104364. [CrossRef]

67. Wang, G.; Xie, M.; Ma, J.; Guan, J.; Song, Y.; Wen, Y.; Fang, D.; Wang, M.; Tian, D.-A.; Li, P. Is Co-Infection with Influenza Virus a Protective Factor of COVID-19? SSRN Electron. J. 2020. Available online: https: //papers.ssrn.com/sol3/papers.cfm?abstract_id=3576904 (accessed on 17 October 2020). [CrossRef]

Publisher's Note: MDPI stays neutral with regard to jurisdictional claims in published maps and institutional affiliations.

(C) 2020 by the authors. Licensee MDPI, Basel, Switzerland. This article is an open access article distributed under the terms and conditions of the Creative Commons Attribution (CC BY) license (http://creativecommons.org/licenses/by/4.0/). 